\title{
RADIOCARBON DATING OF THE NEOLITHIC EARLY BRONZE AGE SITE OF MANDALO, W MACEDONIA
}

\author{
YANNIS MANIATIS \\ Archaeometry Laboratory, National Centre for Scientific Research Demokritos \\ 15310 Aghia Paraskevi, Attiki, Greece \\ and \\ BERND KROMER \\ Institut für Umweltphysik, Universität Heidelberg \\ Im Neuenheimer Feld 366, Heidelberg, Federal Republic of Germany

\section{INTRODUCTION}

The following list of dates was obtained in a joint German-Greek project to establish a radiocarbon dating laboratory in the National Research Centre for Physical Sciences "Demokritos," Athens, Greece. ${ }^{1}$ Although our initial aim in selecting these samples was to study laboratory procedures, we found that when the dates were arranged in stratigraphic order they provided a chronological framework for Thessalian and northern Macedonian site of the Late Neolithic and Early Bronze Ages (Kotsakis et al 1989; Papanthimou \& Papasteriou 1987a).

The dates were obtained by $\mathrm{CO}_{2}$ gas counting in the Heidelberg laboratory (Schoch et al 1980). Dates are expressed as radiocarbon years relative to 1950 (Stuiver \& Polach 1977) and are corrected for isotopic fractionation. Errors quoted are based on counting statistics of sample, background and standard (SRM 4990) and expressed as 1 standard deviation (o).

All samples listed here come from the prehistoric site of Mandalo in Western Macedonia, $\left(40^{\circ} 52^{\prime} \mathrm{N}, 22^{\circ} 13^{\prime} \mathrm{E}\right) 65 \mathrm{~km}$ northwest of Thessaloniki. The site is being excavated by archaeologists A Pilali-Pasteriou, A Papanthimou-Papaefthimiou and K Kotsakis of the University of Thessaloniki and T Savopoulou of the Archaeological Museum of Thessaloniki. The samples were all charcoal and were submitted by the excavators (Papasteriou et al 1983; Papanthimou \& Papasteriou 1987b).

The site of Mandalo is approximately $20 \mathrm{~km}$ west of the classical capital of Macedonia Pella. It is in the foothills of Mount Paikou in the lowland hills that separate the now dried Yannitsa Lake from Aridaia Plain. It is a small tell site that covers an area of not more than $0.2 \mathrm{ha}$ in its base, and has a height of $7 \mathrm{~m}$. The site can be divided into 4 occupational phases: Ia, Ib, II and III. Mandalo is perhaps the first prehistoric site in Greece that has been radiocarbon dated so consistently and systematically. It therefore provides a very significant chronological reference.

\section{ARCHAEOLOGICAL SAMPLES}

\section{HD-9597. D12}

$6630 \pm 100$

Sample directly overlay sterile layer.

$\delta^{13} \mathrm{C}=-24.8 \% 0$

Comment: date is considered too early.

${ }^{1}$ The laboratory is now fully operational. It will use the code designation, DEM. 
HD-9601. $\quad 4007$ $5710 \pm 150$

Sample from destruction level, probably floor, Mandalo Phase Ib. $\delta^{13} \mathrm{C}=-22.0 \%$ 。

HD-9562. 3120 $5600 \pm 70$

Sample from earliest floor of last house in Mandalo Phase Ib. $\delta^{13} \mathrm{C}=-25.8 \%$

HD-9265. $\quad 4020$ $5540 \pm 70$

Sample from postholes of a house, Mandalo Phase $\mathrm{Ib}$.

$\delta^{13} \mathrm{C}=-24.1 \%$ HD-9557. $\quad 5032$ $5440 \pm 60$

Sample from destruction of the latest house of Mandalo Phase Ib.

$\delta^{13} \mathrm{C}=-25.3 \%$

HD-9559.

2156

$5490 \pm 60$

$\delta^{13} C=-24.7 \% 0$

Sample from destruction layer of a pile house; underlain by baby burial in vase, Mandalo Phase II.

HD-9563. 2202a

$5430 \pm 70$

$\delta^{13} \mathrm{C}=-24.0 \%$

Sample from earliest part of Mandalo Phase II; corner of house built with wooden posts.

HD-9939.

2202b

$5430 \pm 45$

Second sample from same layer; dated to check consistency.

$\delta^{13} \mathrm{C}=-24.3 \%$

HD-9595.

2224

$6410 \pm 190$

Sample from interior of house.

$\delta^{13} \mathrm{C}=-24.7 \%$

HD-9602. 1022

$5460 \pm 100$

Sample from destruction of Mandalo Phase II.

$\delta^{13} \mathrm{C}=-25.2 \%$

HD-9596.

7229

$5290 \pm 70$

$\delta^{13} \mathrm{C}=-24.8 \%$

Sample from same destruction level as 1022, west of stratigraphic section. Sample is associated with storage bin underlying destruction level.

HD-9833. 7253

$5460 \pm 50$

Sample from destruction level of house, Mandalo Phase II.

$\delta^{13} \mathrm{C}=-24.8 \%$

$5340 \pm 100$

HD-9834.

7275

$\delta^{13} C=-25.9 \%$

Sample from yellow layer underlying destruction level, with remains of burned clay and small pieces of charcoal, Phase II. 
HD-9835.

8152

$4300 \pm 100$

$\delta^{13} \mathrm{C}=-26.0 \%$

Sample from layer directly overlying destruction level of Phase II (EBA).

HD-9915. 8231

$4130 \pm 40$

Sample from destruction level of house, Phase III.

$\delta^{13} \mathrm{C}=-25.3 \% 0$

HD-9216. $\quad 7140$

$4130 \pm 70$

Same as HD-9835.

$\delta^{13} \mathrm{C}=-25.7 \%$

HD-9907.

8119

$3920 \pm 40$

Sample from pits that were possibly cut from near surface (EBA).

HD-9146. 1024

$\delta^{13} \mathrm{C}=-25.1 \%$

Same as above.

$3860 \pm 70$

HD-9603.

3040

$\delta^{13} \mathrm{C}=-25.2 \%$

Sample from postholes of wall, Phase Ib.

$5520 \pm 80$

$\delta^{13} \mathrm{C}=-24.8 \%$ 。

HD-9832. 7251

$5420 \pm 40$

Same as HD-9833, above.

$\delta^{13} \mathrm{C}=-24.5 \%$

General Comment: Figure 1 shows the calibrated dates placed in their stratigraphic order. The data were calibrated using the computer program supplied by Stuiver and Reimer (1986). The calibration is based on Stuiver and Pearson (1986), Pearson and Stuiver (1986), Pearson et al (1986), Linick, Suess and Becker (1985), Stuiver et al (1986), Kromer et al (1986) and Linick et al (1986). The age ranges in the figure are represented by bars where the length represents the age range and the height represents the percent probability that the sample is in the specific range.

It is obvious that the dates form two well-defined groups. Phases Ib and II are clearly dated to the 5th millennium $\mathrm{BC}$ whereas Phase III dates to the 3rd millennium. There are no ${ }^{14} \mathrm{C}$ determinations from the 4th millennium. According to archaeological interpretation (Kotsakis et al 1989; Papanthimou \& Papasteriou 1987a) there is no apparent discontinuity in the sampling along the stratigraphic transition between Mandalo II and Mandalo III. Our results corroborate this finding and indicate that habitation was interrupted and resumed at the site after a long period had passed, perhaps as much as a millennium.

On the basis of typological similarities, Mandalo Ib and II can be associated with Malia II, Suplevac, Bakarno-Gumno I-II and Ernobuki I-II (Kotsakis et al 1989; Papanthimou \& Papasteriou 1987a). There are no ${ }^{14} \mathrm{C}$ dates for these Albanian, south Yugoslavian sites. These groups are usually linked with the Rachmani culture of Thessaly. 


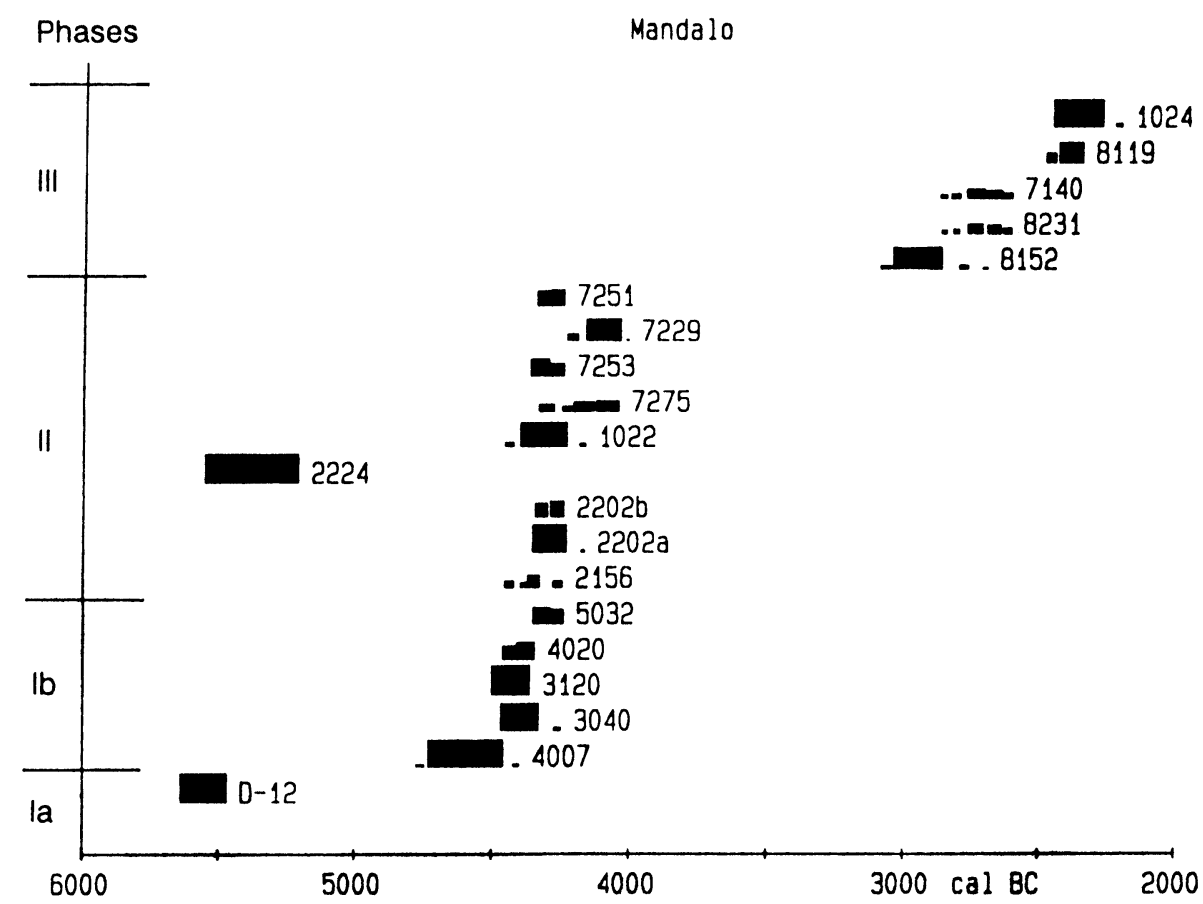

Fig 1. The distribution of dates for the Mandalo site, West Macedonia, Greece. The length of the bars represents the age range; the height represents the percent probability that the sample lies in the specific range.

\section{ACKNOWLEDGMENTS}

The construction of the radiocarbon laboratory of the NRCPS "Demokritos," Athens, Greece was financed by the Volkswagen Foundation, Hannover, West Germany. The authors are grateful to the Foundation and especially to Dr Marie-Luise Zarnitz and Dr G Dege. The ${ }^{13} \mathrm{C}$ analyses were made by $\mathrm{C}$ Junghens. Many thanks are due the archaeologists for supplying the samples and for useful information and discussions concerning their archaeological context.

\section{REFERENCES}

Kotsakis, K, Papanthimou-Papaefthimiou, A, Pilali-Papasteriou, A, Savopoulou, T, Maniatis, Y and Kromer, B 1989 Carbon-14 dates from Mandalo, W Macedonia. In Maniatis, Y, ed, Archaeometry, Internatl symposium on archaeometry. Amsterdam, Elsevier: 679-685.

Kromer, B, Rhein, M, Bruns, M, Schoch-Fischer, H, Münnich, KO, Stuiver, M and Becker, B 1986 Radiocarbon calibration data for the 6th to the 8th millennia BC. In Stuiver, M and Kra, RS, eds, Internatl ${ }^{14} \mathrm{C}$ conf, 12th, Proc. Radiocarbon 28(2B): 954-960.

Linick, TW, Long, A, Damon, PE and Ferguson, CW 1986 High-precision radiocarbon dating of bristlecone pine from 6554 to 5350 BC. In Stuiver, M and Kra, RS, eds, Internatl ${ }^{14} \mathrm{C}$ conf, 12th, Proc. Radiocarbon 28(2B): 943-953.

Linick, TW, Suess, HE and Becker, B 1985 La Jolla measurements of radiocarbon in south German oak tree-ring chronologies. Radiocarbon 27(1): 20-32. 
Papanthimou, A and Papasteriou, A 1987a New excavations at Mandalo, W Macedonia 1985-86. Bull Philosophy School, Univ Thessaloniki, in press.

1987b The prehistoric site of Mandalo, W Macedonia in the cultural framework of the Late Neolithic. In Internatl conf on the prehistoric Aegean, Athens.

Papasteriou A, Papanthimou, A, Kotsakis, K and Savopoulou, T (ms) 1983 New prehistoric site at Mandalo, W Macedonia. Paper presented at Internatl symposium on ancient Macedonia, Thessaloniki Dec 15-17.

Pearson, GW, Pilcher, JR, Baillie, MG, Corbett, DM and Qua, F 1986 High-precision ${ }^{14} \mathrm{C}$ measurements of Irish oaks to show the natural ${ }^{14} \mathrm{C}$ variations from $\mathrm{AD} 1840$ to $5210 \mathrm{BC}$. In Stuiver, $\mathrm{M}$ and $\mathrm{Kra}$, RS, eds, Internatl ${ }^{14} \mathrm{C}$ conf, 12 th, Proc. Radiocarbon 28(2B): 911-934.

Pearson, GW and Stuiver, M 1986 High-precision calibration of the radiocarbon time scale, 500-2500 BC. In Stuiver, M and $\mathrm{Kra}$, RS, eds, Internatl ${ }^{14} \mathrm{C}$ conf, 12 th, Proc. Radiocarbon 28(2B): 839-862.

Schoch, H, Bruns, M, Münnich, KO and Münnich, M 1980 A multi-counter system for high-precision carbon-14 measurements. In Stuiver, $\mathrm{M}$ and $\mathrm{Kra}$, RS, eds, Internatl ${ }^{14} \mathrm{C}$ conf, 10th, Proc. Radiocarbon 22(2): 442-447.

Stuiver, M, Kromer, B, Becker, B and Ferguson, CW 1986 Radiocarbon age calibration back to 13,300 years BP and the ${ }^{14} \mathrm{C}$ age matching of the German oak and US bristlecone pine chronologies. In Stuiver, M and Kra, RS, eds, Internatl ${ }^{14} \mathrm{C}$ conf, 12th, Proc. Radiocarbon 28(2B): 969-979.

Stuiver, M and Pearson, GW 1986 High-precision calibration of the radiocarbon time scale, AD 1950-500 BC. In Stuiver, $\mathrm{M}$ and $\mathrm{Kra}$, RS, eds, Internatl ${ }^{14} \mathrm{C}$ conf, 12 th, Proc. Radiocarbon 28(2B): 805-838.

Stuiver, M and Polach, HA 1977 Discussion: Reporting of ${ }^{14} \mathrm{C}$ data. Radiocarbon 19(3): 355-363.

Stuiver, M and Reimer, PJ 1986 A computer program for radiocarbon age calibration. In Stuiver, M and Kra, RS, eds, Internatl ${ }^{14} \mathrm{C}$ conf, 12th, Proc. Radiocarbon 28(2B): 1022-1030. 